\title{
Currency Risk of Public Debt in Serbia: Current Status and European Lessons
}

\author{
Article history: \\ Received: 27 November 2017 \\ Sent for revision: 12 December 2017 \\ Received in revised form: 8 August 2018 \\ Accepted: 10 August 2018 \\ Available online: 2 October 2018
}

\begin{abstract}
Currency risk, and its effect on public debt, is becoming more important in economic analysis, particularly in highly dollarized countries like Serbia. The aim of this paper is to analyse the currency structure of the public debt in Serbia and the associated risks, and to present the recommendations for improving public debt management based on international experiences. This paper analyses the currency structure of public debt of Serbia over the period 2004-2016, the comparative indicators of dollarization in Serbia and selected countries of the region, as well as the currency risk movements. The currency structure of the public debt of Serbia characterizes the predominance of three currencies - dinar, dollar and euro. Serbia is the most euroised country in the region, along with a marked highest share of dollar debt in total public debt. As a result, due to currency mismatch, the public debt of Serbia is exposed to high currency risk. Based on the presented successful examples of public debt management in Hungary and Poland, as countries with a low level of dollarization, the recommendations for improving public debt management system in Serbia are presented in the final section of our paper.
\end{abstract}

Key words: public debt, currency structure of public debt, Serbia, dedollarization, Hungary, Poland.

\section{Uticaj valutnog rizika na javni dug u Srbiji: stanje i evropska iskustva}

Apstrakt: Valutni rizik i njegov uticaj na kretanje javnog duga dobija sve više na značaju u ekonomskim analizama naročito u visoko dolarizovanim

\footnotetext{
${ }^{1}$ Metropolitan University, FEFA, gradosavljevic@fefa.edu.rs

${ }^{2}$ Ministry of Finance of the Republic of Serbia, Public Debt Administration 
Radosavljević G., Tomov V.: Currency Risk of Public Debt in Serbia: Current Status...

zemljama poput Srbije. Cilj rada je analiza valutne strukture javnog duga Srbije i rizici koje ona nosi te uz predstavljanje međunarodnih iskustava davanje preporuka za unapređenje upravljanja javnim dugom. U radu je analizirana valutna struktura javnog duga Srbije u periodu od 2004. do 2016. godine, zatim uporedni pokazatelji dolarizacije Srbije $i$ odabranih zemalja regiona, kao i kretanje valutnog rizika u istim. Valutnu strukturu javnog duga Srbije karakteriše veliki udeo tri valute - dinara, dolara i evra. Srbija je najviše evroizovana zemlja u regionu uporedo sa upadljivo najvećim učešćem dolarskog duga u ukupnom javnom dugu. Time je usled valutne neusklađenosti javni dug Srbije izložen visokom valutnom riziku. Na osnovu predstavljanja uspešnih primera upravljanja javnim dugom u Mađarskoj $i$ Poljskoj, kao zemljama sa niskim stepenom dolarizacije, na kraju rada date su preporuke za unapređenje sistema upravljanja javnim dugom u Srbiji.

Ključne reči: javni dug, valutna struktura javnog duga, Srbija, dedolarizacija, Mađarska, Poljska.

\section{Introduction}

The guidelines for public debt management developed by the IMF and the World Bank point out several dilemmas and problems that developing countries are faced with managing public debt (IMF\&World Bank, 2014). In doing so, they emphasize the need to pay particular attention to risk management relating to foreign currency debt. It is highly likely to have a situation where foreign currency borrowing is at a given moment less expensive than domestic currency borrowing with the same maturity date. However, ultimately, this borrowing may prove actually more expensive. Most often, the reason for this is the currency risk involved in the case of domestic currency depreciation. Currency structure is the cause of currency risk as a result of changes of foreign currency rates in relation to domestic currency, but also based on the interrelationship of foreign currencies. The changes of currency with a greater share in the currency structure of public debt will have a greater effect on its movement.

Governments should aim to reduce such risk by borrowing in domestic currency, possibly with a longer maturity date. However, countries with an underdeveloped domestic market are not in a position to implement anything like this, hence, the authorities must choose between issuing short-term domestic instruments and long-term securities indexed or denominated in foreign currency. Therefore, developing the domestic market should be a priority for these countries.

A major comprehensive fiscal reform in Serbia started in 2001 following the democratic changes in the country, its goal being regulating the fiscal system 
Radosavljević G., Tomov V.: Currency Risk of Public Debt in Serbia: Current Status...

modelled on the fiscal system of the European Union (EU). The reform included enacting new tax laws, budgetary reforms, the establishment of a treasury, the reform of the tax administration and tax procedure, local selfgovernment financing, etc. This was later followed by the process of public debt management primarily as a result of the need for negotiation with the Paris and London Club creditors in reference to the write-off of debt. After the first few years of transition and the reforms of public finance, and the first borrowings and issuing of securities on the domestic market, a system of public debt management was set in place with the establishment of the Public Debt Administration. Also, by that time, currency structure changed, primarily as a result of increased dinar debt. In addition to the dinar, the structure of public debt of Serbia comprises also two major rivalling world currencies, the euro and the dollar. Any change in the euro/dollar relationship results in significant consequences on the level of public debt of Serbia, due to their high share in the currency structure. The aim of this paper is to analyse currency risks that exist in the structure of public debt of Serbia and to present, in the consideration of international experiences, the recommendations for improving the public debt management system.

\section{Public debt - theoretical base}

There is no simple or unique method of public debt management, or method to reduce currency risk. Different authors propose and describe different methods, such as fiscal stabilisation, public debt restructuring, macroeconomic stabilisation, developing the domestic financial market, all of which should influence public debt sustainability. According to Reinhart et al. (2015), "countries with external debt, denominated in foreign currency, regulated by foreign courts, have many more limiting measures than countries whose debt is in the hands of domestic investors, for the largest part in domestic currency and regulated by domestic laws" (p. 33-34). Often the only solution for these former countries is debt restructuring, since printing money, due to inflation, is a measure impossible to enforce. Countries with the major share of external debt face greater refinancing risk than countries with internal debt as the latter can simply print money in order to pay off the debt. This is why these countries mainly rely, in addition to debt restructuring, on the adjustment of primary balances, economic growth, and even the introduction of wealth taxation (Reinhart et al., 2015).

Borensztein (2004) points out that "developing countries are in a very difficult position when it comes to long-term debt in domestic currencies" (p. 3). Their public debt relies on short-term structures and foreign currencies, due to a higher degree of vulnerability to debt crises. Short-term debts are more sensitive and volatile and all external shocks are relatively quickly manifested 
Radosavljević G., Tomov V.: Currency Risk of Public Debt in Serbia: Current Status...

in these instruments. This problem leads to much more serious challenges such as lack of a credible monetary and fiscal policy. However, developing the domestic market and the development of domestic private pension funds usually creates a sound starting investment base for long-term investments. In addition, the large share of foreign currency debt may very quickly lead to insolvency as a result of domestic currency depreciation (Borensztein, 2004).

Abbas and Christensen (2010) studied the role of debt in domestic currency and the development of the market of domestic securities in developed countries and in developing countries. Their study generated several conclusions. The moderate levels of the share of domestic currency debt (approx. 35\%) have a positive impact on economic growth. Domestic debt influences economic growth via several channels - improved monetary policy, financial market development, the strengthening of domestic institutions, the increase of private savings and financial intermediation.

On numerous times in the past, the development of the domestic capital market, especially in developing countries, has been pointed out as a method for ensuring sustainability and public debt management. Arnone and Presbitero (2007) examined the development of domestic financing. Domestic financing is becoming more popular and more important in many countries. Creating and developing the domestic securities market in developing countries can stimulate the development of international markets in terms of liquidity and depth, thereby reducing the effects of external shocks. Well managed, domestic debt influences the reduction of interest rate risks and currency risks to which public debt is exposed to. The development of the domestic government securities market requires the support of the monetary policy. In time, the liquid, deep market, once developed, will help and influence the reduction of financing costs. In addition, the development of the domestic securities market is necessary for strengthening the process of sustainable economic development as it mobilizes domestic savings and, provided that the market is well organized, leads to an efficient allocation of capital (Arnone and Presbitero, 2007).

The currency structure of public debt is also the subject of careful consideration in terms of currency crises, but also in terms of debt crises. In a large number of cases, these crises result from one another i.e. they occur simultaneously and jointly. Claessens et al. (2003) point out that "quite often developing countries find it less expensive to borrow in foreign currency which implies greater currency risk, particularly if revenues of the state are in domestic or some other foreign currency" (p. 2-3). This is the case of Serbia, as discussed in detail in the next section. 
Radosavljević G., Tomov V.: Currency Risk of Public Debt in Serbia: Current Status...

\section{Currency structure of public debt in Serbia}

For the purpose of this analysis, we examined the period from 2004 to 2016 and the data relating to the amount and the structure of public debt of Serbia. Presented data was retrieved from the Ministry of Finance of the Republic of Serbia, Public Debt Administration. In 2004, when compared to 2000, the share of dinar debt increased as a result of the issuing short-term government securities, the dollar debt was reduced, while the share of euro-denominated debt increased ${ }^{3}$. If we look at the movement of currency structure in the subsequent years, we notice that approximately $90 \%$ of public debt is determined by three currencies - dinar, euro and dollar.

Table 1. Currency structure of public debt of Serbia, 2004-2016

\begin{tabular}{|c|c|c|c|c|c|c|}
\hline & RSD & EUR & USD & CHF & SDR & Other currency \\
\hline 2004 & $3.49 \%$ & $63.47 \%$ & $29.69 \%$ & - & $3.53 \%$ & - \\
\hline 2005 & $7.32 \%$ & $58.39 \%$ & $30.45 \%$ & - & $3.84 \%$ & - \\
\hline 2006 & $6.06 \%$ & $61.54 \%$ & $27.95 \%$ & - & $4.45 \%$ & - \\
\hline 2007 & $3.65 \%$ & $75.65 \%$ & $13.80 \%$ & - & $4.80 \%$ & $2.10 \%$ \\
\hline 2008 & $2.60 \%$ & $75.40 \%$ & $14.50 \%$ & - & $5.30 \%$ & $2.30 \%$ \\
\hline 2009 & $12.80 \%$ & $66.30 \%$ & $13.20 \%$ & $1.90 \%$ & $4.80 \%$ & $1.10 \%$ \\
\hline 2010 & $14.60 \%$ & $60.00 \%$ & $14.70 \%$ & $1.70 \%$ & $7.90 \%$ & $1.00 \%$ \\
\hline 2011 & $16.10 \%$ & $56.50 \%$ & $18.40 \%$ & $1.40 \%$ & $6.80 \%$ & $0.90 \%$ \\
\hline 2012 & $19.10 \%$ & $50.80 \%$ & $22.70 \%$ & $1.20 \%$ & $5.60 \%$ & $0.60 \%$ \\
\hline 2013 & $20.30 \%$ & $45.80 \%$ & $27.80 \%$ & $0.90 \%$ & $4.60 \%$ & $0.60 \%$ \\
\hline 2014 & $21.40 \%$ & $41.70 \%$ & $34.50 \%$ & $0.70 \%$ & $4.20 \%$ & $0.50 \%$ \\
\hline 2015 & $22.20 \%$ & $39.80 \%$ & $32.90 \%$ & $0.60 \%$ & $3.90 \%$ & $0.60 \%$ \\
\hline 2016 & $20.90 \%$ & $39.70 \%$ & $33.90 \%$ & $0.50 \%$ & $3.70 \%$ & $1.30 \%$ \\
\hline
\end{tabular}

Source: Public Debt Administration, Ministry of Finance of the Republic of Serbia

After 2000 , and especially after 2004 , the share of dinar debt increased, as well as the euro-denominated debt, while the dollar-denominated debt decreased. The share of dinar debt in public debt increased from $3.49 \%$ in 2004 to $12.80 \%$ in 2009 as a result of issuing on the domestic market shortterm treasury bills starting in 2004 , followed by long-term treasury bills starting in 2006. The share of euro debt increased from $43.64 \%$ in 2004 to approximately $75 \%$ over the period $2007-2008$, reaching its maximum level. At the same time, the share of dollar debt decreased, mostly owing to the write-off of a large portion of liabilities towards the Paris and London Clubs. Its share dropped from $52.12 \%$ in 2000 to $13.12 \%$ in 2009 . The period 2008-

${ }^{3}$ Data for the period prior to 2004 are not available, with the exception of the year 2000 .

Industrija, Vol.46, No.3, 2018 
Radosavljević G., Tomov V.: Currency Risk of Public Debt in Serbia: Current Status...

2009 presents another turning point in the movement of currency structure of public debt. The share of dinar debt continued to rise throughout this period, until the end of the period when it reached $20.90 \%$. The share of eurodenominated debt gradually dropped until the end of the period observed when it reached $39.70 \%$, representing the lowest level in the period observed. This share was reduced in spite of the start of issuing of short-term and longterm dinar securities on the domestic market in 2011, however due to a new increase of the share of dollar-denominated debt. Namely, that same year Serbia started issuing its first Eurobonds, which is to continue in 2012 and 2013. These issues were worth approximately 1 bn USD and more, which currently accounts for $1 / 5$ of total public debt just based on these securities. Together with other USD liabilities and loans, the share of dollar debt increased from $13.20 \%$ in 2009 to $33.90 \%$ in 2016 .

We are now going to analyse the share of foreign debt in total public debt. It is a clear indicator of the portion of public debt that is exposed to currency risk, i.e. the public debt increase as a result of foreign currency changes (currency basket) in which the public debt is denominated. A higher value of this indicator means higher currency risk, i.e. risk resulting from the change of the level of public debt. The share of foreign debt in total public debt over the course of the observed period dropped from $96.51 \%$ to $79.10 \%$. However, this percentage amount is still considered very high.

Graph 1. Share of foreign debt in public debt over the period 2004-2016

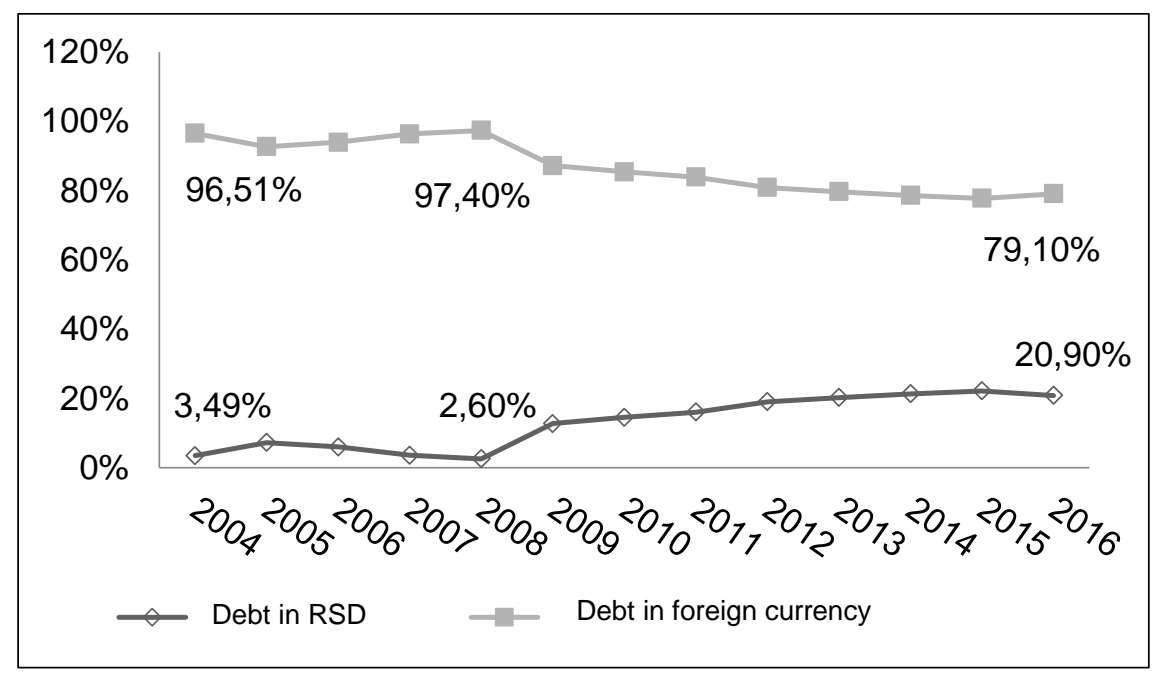

Source: Ministry of Finance of the Republic of Serbia 
Radosavljević G., Tomov V.: Currency Risk of Public Debt in Serbia: Current Status...

If we look at the indicators of dollarization, or euroization, in the countries of the region (Table 2) it may be concluded that Serbia, along with Croatia, is a country with the highest degree of euroization of all countries of SouthEastern Europe. B\&H and Albania have the highest share of foreign currency loans, but a lower share of foreign currency deposits.

Table 2. Indicators of dollarization in European countries, 2014-2016, in \%

\begin{tabular}{|l|c|c|c|l|c|c|c|}
\hline \multicolumn{4}{|c|}{ Foreign currency loans } & \multicolumn{4}{c|}{ Foreign currency deposits } \\
\hline & 2014 & 2015 & 2016 & & 2014 & 2015 & 2016 \\
\hline Serbia & 70.6 & 73.5 & 70.7 & Serbia & 72.1 & 70.2 & 69.3 \\
\hline Croatia & 67.0 & 66.0 & 60.0 & Croatia & 67.0 & 67.0 & 64.0 \\
\hline B\&H & 65.0 & 65.0 & 58.5 & B\&H & 49.2 & 46.9 & 56.4 \\
\hline Albania & 58.0 & 56.0 & 53.0 & Albania & 48.0 & 50.0 & 52.0 \\
\hline Macedonia & 52.0 & 55.0 & 48.0 & Macedonia & 65.0 & 65.0 & 65.0 \\
\hline Romania & 57.0 & 50.0 & 43.0 & Romania & 33.0 & 32.0 & 31.0 \\
\hline Bulgaria & 57.0 & 52.0 & 46.0 & Bulgaria & 27.0 & 25.0 & 31.0 \\
\hline Hungary & 42.0 & 30.0 & 39.0 & Hungary & 27.0 & 25.0 & 31.0 \\
\hline Poland & 27.0 & 26.0 & 25.0 & Poland & 9.0 & 10.0 & 11.0 \\
\hline Czech Republic & 20.0 & 19.0 & 19.0 & Czech Republic & 12.0 & 12.0 & 11.0 \\
\hline
\end{tabular}

Source: Central banks of selected countries

Czech Republic and Poland have a very low rate of dollarization, their foreign currency deposits accounting for up to $12 \%$ of total deposits, with foreign currency loans accounting for up to $27 \%$ of total loans. Hungary and Bulgaria also have an acceptable rate of dollarization in terms of deposits which are in the range of approximately $30 \%$ of total foreign currency deposits, but with a higher rate in terms of foreign currency loans, with a declining trend over the past years. It may be concluded that the countries of the Western Balkans are more inclined towards euroization than other surrounding countries - EU members who have kept their domestic currencies. A common reason for this is found in the low level of trust in domestic currency and the macroeconomic instability as a result of a common political history. The most significant currency in foreign currency loans and deposits in these countries is the euro.

We will also compare the share of dollar debt in total public debt in Serbia and countries in the region with a similar degree of euroization in the structure of exports (Table 3). Serbia, as a country with the lowest share of domestic currency debt in the currency structure of public debt, is a country with the highest share of dollar debt in total public debt. The share of dollar debt is higher than the share of dollar debt in countries with a similar or somewhat lower degree of euroization, and in countries with a low level of euroization. 
Radosavljević G., Tomov V.: Currency Risk of Public Debt in Serbia: Current Status...

Table 3. Currency structure of public debt of countries in the region in 2015

\begin{tabular}{|l|c|c|c|c|}
\hline & Domestic currency & EUR & USD & Other \\
\hline Serbia & $22.20 \%$ & $39.70 \%$ & $33.90 \%$ & $4.20 \%$ \\
\hline Croatia & $21.40 \%$ & $74.40 \%$ & $4.10 \%$ & $0.10 \%$ \\
\hline B\&H & $22.50 \%$ & $49.60 \%$ & $17.30 \%$ & $10.60 \%$ \\
\hline Macedonia & $25.60 \%$ & $64.60 \%$ & $0.60 \%$ & $9.20 \%$ \\
\hline Albania & $53.00 \%$ & $32.46 \%$ & $10.05 \%$ & $4.49 \%$ \\
\hline Romania & $49.50 \%$ & $40.60 \%$ & $8.97 \%$ & $0.93 \%$ \\
\hline Bulgaria & $23.03 \%$ & $75.93 \%$ & $0.40 \%$ & $0.64 \%$ \\
\hline Hungary & $66.40 \%$ & $14.80 \%$ & $14.30 \%$ & $4.50 \%$ \\
\hline Czech Republic & $83.70 \%$ & $15.20 \%$ & $0.00 \%$ & $1.10 \%$ \\
\hline Poland & $65.00 \%$ & $26.50 \%$ & $4.70 \%$ & $3.80 \%$ \\
\hline
\end{tabular}

Source: Public debt reports, Ministries of Finance of the named countries

Czech Republic has no dollar denominated public debt, while in Macedonia and Bulgaria this percentage amount is very low, under $1 \%$. Other countries with a share of domestic currency in public debt similar to that of Serbia's account for a low share, such as Croatia $(4.7 \%)$ and $\mathrm{B} \& \mathrm{H}(7.3 \%)$ or somewhat higher in the case of Romania $(9,7 \%)$, Albania (10\%) or Hungary $(15 \%)$. The share of dollar debt of Hungary should be taken with some reservation as according to the latest data the repaid debt to IMF was not excluded, making this debt even lower. Therefore, if compared to the next highest ranked country according to the share of dollar debt, Serbia's share of dollar debt is at least double, while when compared to Croatia, that debt share is almost 7 times higher.

\section{Graph 2. Changes in Selected Exchange Rates in Serbia}

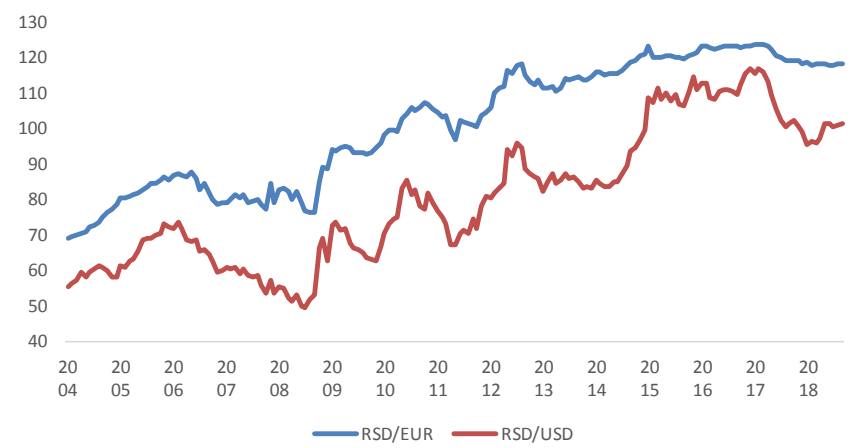

Source: National Bank of Serbia 
Radosavljević G., Tomov V.: Currency Risk of Public Debt in Serbia: Current Status...

One of the important parameters for decisions on currency allocation of foreign-currency debt is the degree of uncertainty concerning future movements in exchange rates (Malecky, 2012). High volatility of exchange rate is the indicator of high currency risk in Serbia and confirms the need for the implementation of appropriate measures of fiscal policy, supported by a monetary policy, for reducing the same. The high level of volatility of the exchange rate makes public debt management uncertain, especially when it comes to debt denominated in USD (Graph 2). Moreover, the standard deviation of RSD/USD exchange rate over the 2004-2018 period is around 17.33, while the standard deviation of RSD/USD exchange rate over the same period is 19.09, showing again higher uncertainty of debt denominated in USD. As we can see in Table 3 , Serbia has biggest share od USD denominated debt comparing with CEE and Western Balkan countries.

In consideration of the fact that other countries, also have a similar or the same currency structure of revenues (mostly in domestic currencies and euro), such a high share of Serbia's dollar debt causes concern. In the case of currency mismatch, the euro-dollar ratio adversely affects the movement of public debt in Serbia. Therefore, when compared to the other countries, it is evident that the high share of dollar debt is what is causing the highest currency risk in Serbia and influencing movements in public debt levels. ${ }^{4}$

\section{Currency risk management - European experiences and recommendations}

Countries like Poland and Hungary have in the previous period managed to increase the share of domestic currency in the structure of public debt through fiscal and monetary policy measures. This directly impacted the reduction of currency risk and stabilisation of public debt. All of these countries encountered at a certain point in time an increase of the share of foreign currency debt in total public debt. We believe that these two cases can adequately show which measures for the reduction of public debt currency risk in practice could be considered and implemented in Serbia.

\subsection{Currency risk and domestic market development in Hungary}

Similarities between Hungary's experience and Serbia refer to the high level of indebtedness with which they entered the process of transition, as well as a

\footnotetext{
${ }^{4}$ For example, over the period May - December 2016, the dollar strengthened by approximately $11 \%$, resulting in the increase in public debt levels by 1.06 billion euros. On the other hand, in the course of 2017 the dollar weakened, whereby the public debt was reduced by approximately 1.2 billion euros.
} 
Radosavljević G., Tomov V.: Currency Risk of Public Debt in Serbia: Current Status...

high degree of euroization. On the other hand, macroeconomic growth was not always followed by use of external capital, which lead to even higher indebtedness over the years. In addition, it points out that in the end of the '80s, Hungary's public debt was $100 \%$ denominated in foreign currency (Barcza, 2015).

During the '90s, with the liberalization of financial markets, and with the development of the domestic financial market, Hungary managed to stabilise its public debt and to restructure it by reducing the share of foreign currency debt through borrowings on the domestic market. This entailed a high level of domestic borrowings, on a market that matured over the years, allowing, i.e. creating conditions for the issue and investment in long-term, instead of shortterm instruments. The reduction of foreign debt was also the result of negotiations with the Paris and London Clubs and a write-off of a portion of the debt. In this period, the National Bank of Hungary (MNB) began handling the management of public debt. Debt restructuring implied two processes restructuring by the fiscal authorities and sterilization by the monetary authorities. This was followed by the conversion of foreign debt into forints, by the employing elements of sterilization - reverse repo transactions and government securities (Nemenyi, 1996, p. 251).

The development of the domestic government securities market was unfolded in two phases. The first phase, over the period 1989-1996, included the forming of a primary market and establishing preconditions for the creating a liquid secondary market. The first phase unfolded in a period that was characterized by recession, high budget deficit, high inflation rate and a current account deficit, as a well as a low level of domestic savings. The first steps undertaken related to the establishing of the legislative and the institutional framework. The next important step was attracting potential investors and expanding the investor base. Some of the measures referred to tax incentives for investors investing in securities and the adjustment of the offer of securities in order to meet the needs and demands of investors. At that time, retail trading was introduced for the first time, therefore, distribution was performed through post offices.

The second phase was marked by, first of all, developing of the system of primary dealers and issuing of new types of long term securities. In addition, several measures were introduced for the purpose of improving liquidity and transparency of the secondary market with the intention of developing the same. First, the introduction of benchmark securities, then the introduction of reverse auction, and finally the adjustment of auctions to demand, whereby they were less frequently held, but marked by higher sales volumes. Transparency was improved with the establishing of a plan of financing and calendar of auctions, published at least 6 months in advance, while the most important information on transactions were published on a daily basis. 
Radosavljević G., Tomov V.: Currency Risk of Public Debt in Serbia: Current Status...

Additionally, non-residents were allowed to trade in government securities with maturity over 1 year, and soon this was allowed for short-term securities, which significantly influenced liquidity and deepening of the secondary market. Foreign investors on the domestic market contributed to standardisation of securities and introduction of financial derivatives (Siwinska et al., 1999).

Marer (2010) explains that "over the period 2001-2007 Hungary had a high budget deficit, higher than the countries of the region, and that in 2007 public debt was the highest in the region of Eastern Europe and EMU owing primarily to deferment of structural reforms" (p. 19). Baksay et al. (2012) cite that "prior to the onset of the global economic crisis Hungary managed to decrease the share of its public debt denominated in foreign currency within planned limits, however, the said crisis influenced a new change of the structure of public debt" (p. 181). Barcza (2015) adds that "Hungary was the first country to ask the IMF and EU for financial aid due to the crisis" (p. 439). The demand for bonds denominated in Hungarian forints declined. In view of the fact that financial funds were requested from the EU and IMF, domestic financing was replaced by foreign. In spite of a stable budget deficit the public debt increased, and the share of debt denominated in foreign currency rose to a maximum 44.7\% in 2009 (Baksay et al., 2012). After the crisis, Hungary returned to its goal to bring down its debt-to-GDP ratio, with the Economic Stability Act defining a goal of 50\% of GDP (Barcza, 2015).

Two programmes and several monetary policy measures are implemented. The objective of implementing the programme Funding for Growth Scheme (FGS) was strengthening economic growth, providing financial assistance to the economic sector, primarily to small and medium sized enterprises, boosting the economy, enhancing financial stability and reducing external vulnerability (Laszlo, 2016). All of this was achieved through refinancing and conversion of foreign currency loans with loans in forints, but also through the granting of new loans for investments in forints (Fodor, 2013). This programme influenced two things - economic growth and the dedollarization of the financial system.

The Self-Financing Programme (SFP) brought about the change of the principal instrument of monetary policy and implementation of IRS tenders (MNB, 2015). Two-week repo transactions (MNB bills) were replaced with two-week term deposits with lowering of the reference interest rate and the introduction of currency swaps (Gor-Holecz et al., 2016). The measures taken stimulated banks to invest in domestic government bonds, and the Hungarian ÁKK supported this programme by adjusting the issuing policy to the greater demand for domestic securities. In addition, the development of the retail segment meant that Hungary had an additional channel for financing public debt from practically domestic sources. 
Radosavljević G., Tomov V.: Currency Risk of Public Debt in Serbia: Current Status...

After Czech Republic and Poland, Hungary is today a country with the lowest degree of euroization in the region. The key to the success of the programme for reducing currency risk of public debt was certainly a coordination of activities of the MNB and the ÁKK in the process of public debt management in Hungary. Also, a simultaneous development of the domestic market by way of developing new instruments, increasing market liquidity, the process of dedollarization, along with an economic policy of economic growth incentives yields results in battling currency risk. Improved currency structure is manifested in reduction of debt denominated in foreign currency, as well as in reduction of external vulnerability which was achieved through improved currency structure of public debt.

\subsection{Currency risk management in Poland}

Poland entered the transition with a public debt problem, just as was the case with Hungary. Lisowski (1989) explains that "high public debt originated from the ' 80 s when foreign currency borrowing started growing rapidly, and Poland's inability to repay those debts resulted in deferment of payment" ( $p$. 1827). In this way, public debt continued to increase in the years to come.

According to Windischbauer (2016), at the beginning of the '90s, assets in the form of cash and bank deposits were composed of $75 \%$ foreign and $25 \%$ domestic currency. The first step undertaken towards reducing public debt were negotiations with the London Club creditors which were concluded in 1994. They resulted in conversion of $50 \%$ of debt into so-called Brady bonds, while the other half was written-off. In this way, Poland converted its debt into securities, restructuring the debt in such a way that current repayments, or payments due, are prolonged over a period of several subsequent decades. Among other things, prolonging of maturity dates affects the lowering of financing risk. Therefore, the Brady plan is nothing else but debt securitization. However, as can be seen, debts are still in foreign currency, more precisely in dollars, meaning that there has not been a significant change in the currency structure of Poland's public debt.

According to Plokarz \& Szelagowska (2013), an attempt to resolve the problem of currency risk over the period 1997-2003 was implemented via two principal channels. First, performing buy-back operations, whereby the foreign portion of public debt was bought back in advance, i.e. before maturity. Money for these operations was collected from several sources. The National Bank of Poland issued treasury bills denominated in Polish zlotys (PLN) in 1997, then issued Eurobonds in 2001 in dollars, followed by global bonds and mediumterm euro notes. In this way, the country used new borrowings to finance early repayment of foreign loans, relying in part also on securities denominated in PLN. Also, this method was primarily used for repurchasing Brady bonds and replacing them with domestic debt or high-quality Eurobonds. Second channel 
Radosavljević G., Tomov V.: Currency Risk of Public Debt in Serbia: Current Status...

was the early repayment of foreign debts, based on revenue generated from the privatization of state enterprises and sale of domestic banks to foreign banks. In this way, without any additional borrowings, the country carried out repurchase or early repayment of public debt denominated in foreign currency.

A small portion of the foreign public debt was converted into investments in environmental protection in Poland, as part of the process of the so called eco-conversion. In this way, through debt-for-environment swaps emerged the Polish Ecofund. This fund was established in 1992 under the Paris Agreement. At the time, several countries concluded bilateral agreements with Poland stating that their portion of the debt would be transformed into funds for environmental protection. Thereby, the Polish EcoFund became the first institution in the Central and Eastern Europe established for the purpose of managing the process of conversion of debt for environmental purposes. Donor countries, or former creditors, were the US and Switzerland with 10\% of Polish debt, France with $1 \%$, Sweden with $2 \%$, as well as Finland and Norway $(O E C D, 1998)$. This fund later became one of the most significant instruments in environmental protection and the environment protection policy in Poland.

The importance of domestic market development through increased efficiency, liquidity and transparency of the primary and secondary market in currency risk management was established by IMF and World Bank guidelines, as well as the case of Hungary. One of the first measures implemented in 2003 related to increased issue of benchmark bonds and then reducing the number of securities issue, but with increasing the value of these issues (Ministry of Finance Republic of Poland 2003-2017). Starting in 2008, the number of series was reduced as well as the issue of two-year bonds and government bills, as a result of lower share of short-term instruments in financing government demands for borrowings (Ministry of Finance Republic of Poland 2003-2017).

With the reducing of the share of short-term securities, activities were thereby directed at increasing liquidity of long-term bonds. In the following period, this was achieved with more frequent auctions, i.e. issue of a greater number of existing securities, as well as increased volumes of issue, which was the goal all along. Adapting the policy of securities issue to market conditions, including the sell, switch and buy-back options in issue of new securities. The option to sell allows investors to sell securities at a desired moment. The option to switch, present in the case of Hungarian securities, allows investors or issuer to switch the existing security for a security with a different maturity, while the buy-back option allows the repurchase of security (Ministry of Finance Republic of Poland 2003-2017). 
Radosavljević G., Tomov V.: Currency Risk of Public Debt in Serbia: Current Status...

In addition to this, a system of primary dealers was established in 2003 on the primary market which was limited to 12 banks. The second phase of development of the system of primary dealers included enabling foreign banks to participate in the selection of primary dealers, for the first time in 2005 . Also, Poland's accession to the EU more than opened the doors to foreign banks and foreign investors (Ministry of Finance Republic of Poland 20032017). An efficient organization of the system of primary dealers made it possible for Poland to reduce the costs of debt servicing by eliminating investments in securities issued by other countries which could result from inadequately organized infrastructural development of the Polish financial market, to increase security of financing state budget borrowings and render more attractive the Polish securities market (Ministry of Finance Republic of Poland 2003-2017).

Another method for domestic market development which Poland embraced was development of the segment of retail securities. As a reminder, the system of sale of retail securities relates to those financial instruments which are issued to private individuals. Discussions on this segment began as early as 2002, and one of the main steps in this period in terms of a strategy related primarily to the establishing and later expanding the sales network. This would result in significantly increasing the number of sales points for buyers selling retail bonds, and in initiating new forms of sale (Ministry of Finance Republic of Poland 2003-2017, Debt Strategy 2004). The system of sale of retail securities, addressed primarily to private individuals, was extensively revised as of August 1, 2003. The number of buyers entitled to purchase retail securities on the primary market increased. Retail bonds, with the exception of savings bonds, are now open to purchase not only by private individuals, but also by legal entities and enterprises and enterprises without legal entities other than banks, insurance companies, investment funds, pension funds, brokerage houses, limited liability companies and joint-stock companies. In addition, limitations relating to the sale of foreign currency savings bonds to non-residents were revoked following EU accession (Ministry of Finance Republic of Poland 2003-2017).

A specific characteristic of Poland is that country during the last crisis did not fall into recession but rather recorded a slightly lower than usual positive economic growth. Accordingly, Poland did not have major problems with public debt. Public debt did increase over the period of the crisis to as much as $52 \%$ in 2011 , but it never crossed the legal limit set at $60 \%$ of GDP. In 2016 it is still at the same level, although over the period 2014-2015 it reached approximately $48 \%$ of GDP.

After restructuring of public debt over the transition period when a substantial portion of public debt was written-off and refinanced through the Brady Plan, Poland today continues to employ refinancing and early repayment of the 
Radosavljević G., Tomov V.: Currency Risk of Public Debt in Serbia: Current Status...

same Brady bonds. In addition, domestic market development is established through orientation towards ensuring market liquidity, efficiency and transparency, carrying out buy-back and switch operations. A more attractive market brought about the increase of the number of non-resident investors on the domestic financial market, which influences increased borrowing in domestic currency. All of this contributed to Poland being one of the least dollarized countries in Europe today. Foreign currency deposits in recent years was $9-11 \%$, while the share of foreign currency loans is on the decline, being presently at $25 \%$.

\subsection{Potential implementation of the EU experience in Serbia}

At the beginning of the transition, Serbia's debt was also written-off by the Paris and London Clubs, Serbia effected macro-stabilisation at the beginning of the transition period and cashed in a portion of revenue generated from privatization which led to the reducing of the level of public debt. However, after the trend of public debt decline following the crisis, there is a negative trend in terms of the share of foreign debt, particularly the increase of the share of dollar debt, but also an increase of the level of total public debt. The Public Debt Administration in Serbia was established in 2009 when public debt management formally began, with the first Public Debt Strategy adopted in 2013.

Over the past few years, Serbia carried out certain actions in relation to public debt management. First, over the years, Serbia developed its public debt portfolio. Serbia issued on the international market five Eurobonds with different maturity -5 (two), 7, 9 and 10 years, as well as one amortized bond with maturity of 20 years. In addition, Serbia issues on the domestic market dinar treasury bills and treasury bills denominated in euros, as well as government bonds in both currencies, and one amortized bond in euros. Also, maturity of the mentioned securities spans from 2 to 15 years. In comparison to Hungary and Poland, Serbia has an approximate number of securities.

Second, over the years Serbia developed its secondary market. At the beginning, short-term securities were traded on the secondary market and after some time, with emphasis on 2015, trading with long-term securities began increasing. In order to improve liquidity on the secondary market, some measures employed in Poland and Hungary were implemented, relating mostly to issue of a certain type of securities. In 2011, issued for the first time was a tree-year dinar bond with a coupon, followed next year by the issue of inflation indexed securities and amortized dinar bonds with variable interest rate linked to the reference interest rate of the National Bank of Serbia. Issue of benchmark bonds started in 2015 (maturity 7 years), continuing the following year ( 3 and 7 years). In order to develop the domestic market and local currency, as part of the process of dinarization, EBRD was the first 
Radosavljević G., Tomov V.: Currency Risk of Public Debt in Serbia: Current Status...

international financial institution to issue on the domestic market a three-year dinar bond with a variable interest rate.

Third, the National Bank contributed to public debt management with the process of dinarization of the economy in concord with the Government of the Republic of Serbia. If we look back at the Hungarian example, its MNB implemented two programmes (FGS, SFP) in support of the public debt management strategy in coordination with ÁKK. In the case of Serbia, in recent years, the process of dinarization has been taken to a higher level, according to some indicators. Primarily, in terms of private individuals, the share of loans and domestic currency savings deposits are on the rise, however, they still have not reached the desired level. Also, the term structure of deposits of dinar securities is improving, as well as the currency structure of public debt, however, in terms of borrowings and loans to the economy the process of dinarization has still not reached a satisfactory level. It was in this segment that the MNB reacted, offering the economy ways to borrow in domestic currency and to replace expensive foreign currency loans with less expensive long-term loans in domestic currency.

Fourth, Serbia has made some progress in terms of transparency. The site of the Public Debt Administration of the Ministry of Finance of the Republic of Serbia offers all relevant data. There is a Guide for Investing in government securities, a Portal for Investors containing all information on the schedule of auctions, secondary trade, government securities yield rates, as well as an overview of issued Eurobonds. The Public Debt Administration issues monthly reports informing the public on the movements of public debt, its structure, providing an analysis of issued government securities on the domestic and international market. Therefore, it may be stated that transparency of the overall process of organizing the issue of securities is at a satisfactory level.

In the end of 2017, Serbia started with retail bond program. Retail securities are a direct instrument in fighting currency risk. They contribute to portfolio diversification providing the public with an additional source of investment. As bank deposits are at the moment one of the most affordable means of investments for the public, the institution of retail bonds would mean competition for the banks which could result in the banks improving their offer, particularly in relation to dinars deposits. Moreover, issue of retail securities would contribute to the process of dinarization.

However, in spite of the aforementioned progress made, Serbia has still come only halfway regarding development of the domestic market and using its potential in terms of public debt management. Based on experiences of Hungary and Poland, recommendations for further improvement of the public debt management strategy include the following set of measures: 
Radosavljević G., Tomov V.: Currency Risk of Public Debt in Serbia: Current Status...

1. Institution of primary dealers. The system of market makers used by Poland and Hungary contributed to the development of competition among market participants, reducing the costs of public debt servicing and higher liquidity of the secondary market. Primary dealers offer two-way price quotations which enables maintaining real prices, and their required minimum participation on the primary and secondary market ensures a certain level of constant turnover. This measure was part of Public Debt Managing Strategy since 2017, but still without concrete results. It is also a part of the newest Strategy, which means nothing has done so far.

2. Developing liquidity of the secondary market. Extension of public debt maturity should continue. For example. Hungary issues bonds with maturity of 19 years, while Poland has securities with maturity of 20 and 30 years. Benchmark issue has already started and this should continue in the future. One inflation indexed security was issued in Serbia, and in order to ensure market liquidity and provide incentives for investors more of these bonds should be placed on the market. Inflation indexed bonds (or indexed in relation to the exchange rate of the dinar) could replace securities denominated in euros on the domestic market. In addition, as in the Hungarian and Polish model, buy-back options or repurchase of issued securities should be introduced. Public Debt Managing Strategy 2018 recommends developing liquidity of the secondary market but without specific solutions when it comes to financial instruments which will prolong public debt maturity and enrich the portfolio of instruments.

3. Institution of hedging. It is necessary to start utilizing financial derivatives and to include them in subsequent issues, particularly if planning issue of securities in foreign currency again. When it comes to this recommendation, there is nothing similar mentioned in the last Public Debt Managing Strategy.

4. Educating the public and promoting new instruments. This activity becomes even more important with the institution of retail instruments, Private individuals need to be familiarized with investing on the stock exchange, after which further education and promotion of retail securities needs to be carried out. Public Debt Managing Strategy 2018 states this as a future step as well, but, in general, a higher instance than the Public Debt Administration, and with regard to the process it is carrying out, should consider in the near future an education reform and the introduction of basic economics in the educational system.

5. Increasing the share of domestic public debt should be featured as a clear goal. For example, when Hungary was faced with a rapid growth of the level of public debt and borrowing abroad which 
Radosavljević G., Tomov V.: Currency Risk of Public Debt in Serbia: Current Status...

resulted in the increase of foreign public debt, it clearly made a turn in its strategy and made it its main goal to bring domestic borrowing back to normal. The goal of any strategy is to minimize public debt servicing at an acceptable risk ratio, but when the country is facing serious consequences caused by one type of risk, such as the currency risk in Serbia, then the first step in dealing with the same is to admit that a problem exists and to clearly define it. Secondly, in view of the fact that in recent years Serbia has been realizing the current target of $20-25 \%$ share of domestic public debt, in order to ensure further progress it is necessary to consider increasing the scope in order to ensure improvement. The cases of Hungary and Poland prove that flexible strategic goals encourage problem solving. However, in Public Debt Managing Strategy 2018, target of $25 \%$ is still in effect as a future goal.

6. Amending the purpose and methods of borrowing. Over the last few years, Serbia's borrowing is not followed by any, or only minor investment activity. Borrowing relates mainly to repayment of past debts and, to a great degree, to current consumption. Additionally, this recommendation overcomes the power of Public Debt Agency, which means it should be done at higher level and it is not a part of Public Debt Managing Strategy 2018.

7. Implementing measures for expanding the investor base. The first thing to be considered is the possibility of performing clearing and settlement transactions through an international clearing system, just as Hungary and Poland have already done. Also, there is need to modify the auction platforms so that they can meet the needs of investors. In the future, Serbia needs to introduce issue of dinar bonds on the international market, and to include government securities denominated in domestic currency in some of the global indices of government bonds in developing countries with the intention of expanding the investor base. All mentioned is in line with Public Debt Managing Strategy 2018 but more as a consideration than giving particular solutions.

However, in order to realize all of the above, all the presented measures need to be implemented simultaneously. Aside from the specific measures presented in these case studies, Hungary in particular, it has been shown that better coordination of monetary and fiscal policies is required. In Serbia we have had a case where while the Ministry of Finance stimulated government bills, the NBS maintained a high reference interest rate so investors turned to repo transactions instead of investing in government bills. Today, with the process of dinarization under way, proclaimed by both the NBS and the Government of the Republic of Serbia, the need for coordination is greater than ever. 
Radosavljević G., Tomov V.: Currency Risk of Public Debt in Serbia: Current Status...

\section{Concluding remarks}

Analysis indicates that the share of the public debt of Serbia denominated in US dollars is significant comparing to other EU and the Western Balkan countries. Taking in consideration the high level of the uncertainty of $\mathrm{RSD} / \mathrm{USD}$ exchange rate, currency rate risk on the public debt of Serbia is an important issue. Experience from Hungary and Poland shows that what is required is an economic policy that will enable the growth of the economic sector and thus influence the level of public debt and its share in GDP.

The National bank of Hungary resolved the issue of dollarization of loans by granting interest-free loans for refinancing in domestic currency through banks, whereby expensive loans were replaced with cheap domestic loans, with the possibility of taking out the same loans for new investment projects. In addition, the National bank of Hungary offered the banking sector replacing of securities denominated in foreign currencies with long-term domestic securities. These are examples which Serbia could follow. However, it seems that with the exception of a reduction of the reference interest rate, belatedly when compared to the market trends in Europe, the NBS is not resorting to an active monetary policy. Also, the contributions of the fiscal policy of reducing public debt relate to the stabilisation of the fiscal deficit at 1\% of GDP, the risks stemming from public and state-owned companies, through restructuring and privatization wherever feasible.

Measures like developing primary dealers, emerging liquidity of the secondary market, hedging and expanding the investors base are important for further improvement of the public debt management strategy. Although some of them are a part of Public Debt Strategy of the Republic of Serbia, they are still not implemented in practice. Also, increasing the share of domestic public debt should be featured as a clear goal following with a different program for educating the public and promoting new instruments. Although some of these measures like primary dealers, education of the public and developing liquidity of the secondary market, are mentioned in Public Debt Managing Strategy during the last few years, many of them haven't been done until now. Some of them like hedging aren't given at all, but we think they should be included. As managing the public debt, and precisely the reduction of foreign part of it isn't just a fiscal goal but strategic aim of the state, some measures exit the frame of Public Debt Agency and involve other public institutions to engage. This especially refer to the education of public as well as amending the purpose and methods of borrowing.

Finally, it may prove advantageous to consider the use of debt-to-equity swaps, i.e. debt securitization. Poland managed to eco-convert its debt, in other words, to convert its debt into assets that are used for environmental protection. With the establishing of the Polish Ecofund and the use of the 
debt-for-environmental swaps, this fund today stands as the pillar of the environmental protection policy in Poland. If nothing else, a debate can be opened in order to evaluate how this method could contribute to reducing Serbia's public debt and whether there is an area or policy, environmental protection certainly being one of them, which could benefit from additional funds.

\section{References}

Abbas, S.M.A., \& Christensen, J.E. (2010). The Role of Domestic Debt Markets in Economic Growth: An Empirical Investigation for Low-Income Countries and Emerging Markets. IMF Staff Papers, 57(1), 209-255. doi:10.1057/imfsp.2009.24

Arnone, M., \& Presbitero, A. (2007). External debt sustainability and domestic debt in heavily indebted poor countries. Rivista Internazionale Di Scienze Sociali, no. 115(2), 187-213. Retrieved from: http://www.jstor.org/stable/41624850.

Baksay, , \& et al., (2012). The impact of public debt on foreign exchange reserves and central bank profitability: The case of Hungary, in Fiscal policy, public debt and monetary policy in emerging market economies. Bank for International Settlements. No 67; Retrieved from: https://www.bis.org/publ/bppdf/bispap67l.pdf.

Barcza, (2015). The Challenging Role of Public Debt in Economics and the Basic Principles of Hungarian Debt Management. in Public Finance Quarterly/2015, Budapest: Magyar Nemezeti Bank. Retrieved from: https: //asz. hu/storage/files/files/public-finance-quarterly-articles/2015/a_barcza_2015_4. pdf., 433-446; 4.

Bélyácz, I., \& Kuti, M. (2009). Foreign direct investment and external debt in Hungary: An attempt to examine the macroeconomic capital structure from a new perspective. Society and Economy, 31(2), 211-234. doi:10.1556/socec.31.2009.2.4

Borensztein, E., Jeanne, O., Mauro, P., Zettelmeyer, J., \& Chamon, M. (2005). Sovereign Debt Structure for Crisis Prevention. Washington, D.C.: International Monetary Fund (IMF). doi:10.5089/9781589063778.084

Claessens, S., Klingebiel, D., \& Schmukler, S. (2003). Government Bonds in Domestic and Foreign Currency: The Role of Macroeconomic and Institutional Factors. World Bank. doi:10.1596/1813-9450-2986

Fodor, É. (2013). What Could be the Growth Impact of the Funding for Growth Scheme. E-conom: Online Scientific Journal - Economic Studies. Universitas Hungarie Press, 2(1), 16-32. doi:10.17836/ec.2013.1.016

Gor-Holecz, F., \& et al., (2016). Self-fnancing Programme: Concept and Impact Mechanism. In The first two years of the Self-Financing Programme. Budapest: Magyar Nemezeti Bank. (volume of studeis), 7-36, Budapest: Magyar Nemezeti Bank. Retrieved from: https://www.mnb.hu/letoltes/mnb-the-first-two-years-ofthe-self-financing-programme.pdf.

-IMF, , \& -World Bank, (2014). Guidelines for Public Debt Management. Washington DC: IMF. Retrieved from: https: //www. imf. org/external/np/pp/eng/2014/040114. pdf.. 
Radosavljević G., Tomov V.: Currency Risk of Public Debt in Serbia: Current Status...

Laszlo, A. (2016). Impact of the Funding for Growth Scheme on the Hungarian economy. Financial and Economic Review, ssue, Retrieved from, Vol. 15 I; 6587; 4; http://english.hitelintezetiszemle.hu/letoltes/andras-laszlo.pdf..

Lisowski, J. (1989). Problems of Poland's Foreign Debt. Economic and Political Weekly, Retrieved from, Vol. 24, No. 32, 1827-1828; http://www.jstor.org/stable/4395206..

Marer, P. (2010). The global economic crises: Impacts on Eastern Europe. Acta Oeconomica, 60(1), 3-33. doi:10.1556/aoecon.60.2010.1.2

-Magyar Nemzeti Bank. (2015). The Magyar Nemzeti Bank's self-financing programme. Budapest. Retrieved from: http://www.mnb.hu/letoltes/the-magyarnemzeti-bank-s-self-financing-programme-april-2014-march-2015.pdf.

Ministry of Finance Republic of Poland (2003-2017). Public debt - Debt management strategies. Retrieved from: http://www.mf.gov.pl/en/web/wp/publicdebt/publications/debt-management-strategies

-National bank of Serbia. (2016). Report on dinarization of the financial system of Serbia. Belgrade: NBS. Retrieved from: https://www.nbs.rs/static/nbs site/gen/latinica/90/dinarizacija/din 12 16.pdf.

Nemenyi, J. (1996). Capital inflow, macroeconomic equilibrium, the public $\overline{d e b t}$ and the profit and loss of the National bank of Hungary. Acta Oeconomica, Akadémiai Kiadó. Retrieved from, Vol. 48, No. 3/4 (1996), 241-270; http://www.jstor.org/stable/40729664..

-OECD. (1998). Swapping debt for the environment: The Polish Ecofund. Phare Programme. Retrieved from:: https://www.oecd.org/poland/35156800.pdf.

Plokarz, R., \& Szelagowska, A. (2013). Securitization of the Polish Sovereign No Debt in the International Markets / Securitization of the Polish Sovereign No Debt in the International Markets. Studia Ekonomiczne, Wydawnictwo Uniwersytetu Ekonomicznego w Katowicach. Retrieved from: Https: //www. ue. katowice. pl/fileadmin/_migrated/content_uploads/4_R. Plokarz A Szelagowska Securitization.., Volume 174, 50-62, Wydawnictwo Uniwersytetu Ekonomicznego $w$ Katowicach. Retrieved from: https://www.ue.katowice.pl/fileadmin/ migrated/content uploads/4 R.Plokarz A. Szelagowska_Securitization....pdf.

-Public Debt Management Agency of the Ministry of Finance Republic of Serbia. (2009). Monthly Report: Analysis of Public Debt and General Government Debt. 2009-2017; Retrieved from: http://www.javnidug.gov.rs/default.asp?P=26.

Reinhart, C.M., Reinhart, V., \& Rogoff, K. (2015). Dealing with debt. Journal of International Economics, 96, doi:10.1016/j.jinteco.2014.11.001

Siwinska, , \& et al., (1999). Public Debt Structure and Dynamics in the Czech Republic, Hungary, Poland and Romania. Warsaw: Center for Social and Economic Research (CASE).

-Windischbauer. (2016). Strengthening the role of local currencies in EU candidate and potential candidate countries. Occasional Paper Series, 170 / April 2016 No 170 / April 2016. Retrieved from: https://www.ecb.europa.eu/pub/pdf/scpops/ecbop170.en.pdf?8ca594f1a1391f72 a33d05aca6a0405c. 